\title{
Acquisition of cell-adhesion capability of the surface of crosslinked albumin films irradiated with atmospheric-pressure plasma jets
}

\author{
Tatsuru Shirafuji, Mami Iwamura, Ryosuke Taga, \\ Yukiyasu Kashiwagi, Kota Nakajima, Yuji Ogata, Kenji
} Tanaka, Akira Tachibana and Toshizumi Tanabe

\begin{tabular}{|c|l|}
\hline Citation & Japanese Journal of Applied Physics, 55(7S2): 07LG03 \\
\hline Issue Date & 2017-6-22 \\
\hline Type & Journal Article \\
\hline Textversion & author \\
\hline \multirow{3}{*}{ Rights } & $\begin{array}{l}\text { C } 2016 \text { The Japan Society of Applied Physics. } \\
\text { This is the accepted manuscript version. The final publication is available at } \\
\text { https://doi.org/10.7567/JJAP.55.07LG03 }\end{array}$ \\
& $\begin{array}{l}\text { Please cite only the published version. } \\
\text { 引用の際には出版社版をご確認ご利用ください。 }\end{array}$ \\
\hline DOI & 10.7567/JJAP.55.07LG03 \\
\hline
\end{tabular}

Self-Archiving by Author(s)
Placed on: Osaka City University Repository

Shirafuji, T., Iwamura, M., Taga, R., Kashiwagi, Y., Nakajima, K., Ogata, Y., Tanaka, K., Tachibana, A., \& Tanabe, T. (2016). Acquisition of cell-adhesion capability of the surface of crosslinked albumin films irradiated with atmospheric-pressure plasma jets. Japanese Journal of Applied Physics, 55, 07LG03. https://doi.org/10.7567/jjap.55.07lg03 


\title{
Acquisition of cell-adhesion capability of the surface of crosslinked albumin films irradiated with atmospheric-pressure plasma jets
}

\author{
Tatsuru Shirafuji*1, Mami Iwamura, ${ }^{2}$ Ryosuke Taga, ${ }^{1}$ Yukiyasu Kashiwagi, ${ }^{3}$ Kota \\ Nakajima, ${ }^{1}$ Yuji Ogata, ${ }^{1}$ Kenji Tanaka, ${ }^{1}$ Akira Tachibana, ${ }^{2}$ and Toshizumi Tanabe ${ }^{2}$ \\ ${ }^{1}$ Department of Physical Electronics and Informatics, Osaka City University, Osaka 558-8585 Japan \\ 2 Department of Applied Chemistry and Bioengineering, Osaka City University, Osaka 558-8585 Japan \\ ${ }^{3}$ Osaka Municipal Technical Research Institute, Osaka 536-8553 Japan
}

\begin{abstract}
Crosslinked albumin films, to which L929 cells do not attach by nature, acquire the L929-cell-adhesion capability by irradiation of an atmospheric-pressure plasma jet (APPJ) of He gas. The number of attached cells was $2.6 \times 10^{4}$ cells $/ \mathrm{cm}^{2}$ after the APPJ irradiation for $180 \mathrm{~s}$, while conventional UV photolithography, which was performed in our previous work, required $2 \mathrm{~h}$ to obtain the same order of magnitude of the number of attached cells. The contact angle of samples decreased steeply from 105 to $38^{\circ}$ in the first $10 \mathrm{~s}$ irradiation, but decreased quite gradually from 38 to $32^{\circ}$ with increasing irradiation time from 10 to $180 \mathrm{~s}$. In contrast to the nonlinear variation in the contact angles, the number of attached cells almost linearly increased from $4.5 \times 10^{3}$ to $2.6 \times 10^{4} \mathrm{cells} / \mathrm{cm}^{2}$ with increasing treatment time. X-ray photoelectron spectroscopy of the samples indicated that hydrophilic functional groups of $\mathrm{C}-\mathrm{C}=\mathrm{O}$ gradually formed with increasing APPJ irradiation time up to $180 \mathrm{~s}$. These results suggest that the cell-adhesion capability of the crosslinked albumin films is not simply explained by the decrease in contact angle but also by the formation of oxidized functional groups on the surface. The effects of UV and vacuum UV light from APPJ were negligible, which indicates that the formation of oxidized functional groups on the surface is not caused by photon-assisted surface reactions but by reactions involving chemically active species supplied from APPJ.
\end{abstract}

\section{Introduction}

Microscopic control of cell arrangements, or cell micropatterning, on surfaces is an important technology for realizing biosensors, tissue engineering, and also fundamental research works on cell biology. ${ }^{1-5)}$ Cell micropatterning has been built on two important core technologies. One is preparation of a substrate that does not have the cell-adhesion property. Another is intentional and local control of the cell-adhesion capability of the substrate surface. ${ }^{2,3,6)}$

Yamazoe and coworkers have found that a crosslinked albumin film can be a substrate for cell micropatterning. ${ }^{7,8)}$ The films derived from biopolymers such as albumin have suit- 
able degradability and biocompatibility, and can be employed for clinical use. ${ }^{9,10)}$ They have prepared a patterned cell-adhesive surface by photolithography using UV light with a wavelength of $254 \mathrm{~nm}$, and successfully realized cell micropatterning on the surface. The process proposed by Yamazoe and coworkers, however, still has some issues for the industrialization of this micropatterning technique. One of the issues is the improvement of its throughput. UV photolithography takes $2 \mathrm{~h}$ to obtain appropriate cell-adhesion capability of a crosslinked albumin film, ${ }^{7,11)}$ although it is the most extensively utilized method in cell micropatterning. ${ }^{12-15)}$ Moreover, we must use expensive fused quartz masks for UV photolithography.

Several researchers have already proposed maskless methods for overcoming such issues, which include laser lithography, ${ }^{16)}$ laser ablation, ${ }^{17)}$ laser deposition, ${ }^{18-20)}$ projection lithography, ${ }^{21,22)}$ ink-jet printing, ${ }^{23,24)}$ microcontact printing, ${ }^{25,26)}$ nanocontact printing, ${ }^{27)}$ and ion implantation. ${ }^{28-30)}$ However, laser and ion implantation techniques require expensive equipment. In contact-printing methods, microstructured molds should be prepared. Ink-jet printing has poor spatial resolution. Projection lithography has an issue regarding its process throughput similarly to UV photolithography.

Plasma processes can be used for cell patterning, but early plasma cell patterning methods were not maskless processes. ${ }^{31-36)}$ In 2011, Ayan and coworkers have proposed a maskless plasma process. ${ }^{37)}$ They irradiated an atmospheric-pressure plasma jet (APPJ) of $\mathrm{He} / \mathrm{O}_{2}$ gases on a polyethylene substrate, and obtained cell lines with $10 \mu$ m width on the substrate. Although this technique is promising for fabricating patterned-cell devices, the in vivo use of the devices expected in the future is not possible because polyethylene does not have biocompatibility.

Crosslinked albumin films mentioned above have biocompatibility and are suitable substrates for patterned-cell devices used in vivo. However, no group has investigated the possibility of conferring the cell-adhesion capability on the surface of crosslinked albumin films using APPJ. Thus, we have investigated cell-adhesion characteristics on crosslinked albumin films irradiated with APPJ including evaluation of the process throughput of APPJ irradiation, which was not discussed by Ayan and coworkers. ${ }^{37)}$

\section{Experimental procedure}

The APPJ used in this work was generated from dielectric barrier discharge (DBD) in a fused quartz tube with two cylindrical electrodes, ${ }^{38)}$ as shown in Fig. 1 . The outer and inner diameters of the tube were 6 and $4 \mathrm{~mm}$, respectively. The distance between the two electrodes was $3 \mathrm{~cm}$. The applied voltage had a sinusoidal waveform with a frequency of $10 \mathrm{kHz}$ and 


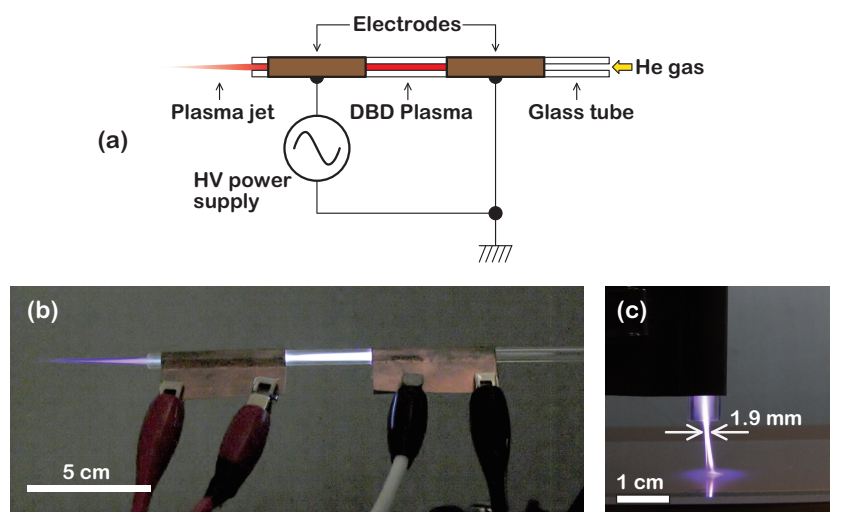

Fig. 1. (Color online) (a) Schematic illustration of the APPJ used in this work and its overview (b) without and (c) with a target.

voltage amplitude of $10 \mathrm{kV}$, which was supplied from a high-voltage amplifier (Trek 10/40A) with a signal generator (Agilent 33522A). The discharge gas was helium with a flow rate of $1.6 \mathrm{~L} / \mathrm{min}$, and the ambient gas was air (the relative humidity was approximately 50\%).

We prepared crosslinked albumin films on Petri dishes (Iwaki; nontreated dish; diameter, $35 \mathrm{~mm}$ ) as described in the previous reports by Yamazoe and coworkers. ${ }^{7,11)}$ APPJ was irradiated on the crosslinked albumin films for 0 to $300 \mathrm{~s}$. The distance between the APPJ nozzle and films was $1 \mathrm{~cm}$. We investigated the cell-adhesion characteristics of the films using mouse fibroblast L929 cells $\left(4.0 \times 10^{5}\right.$ cells/dish $)$ by cell culture assay described in the previous reports by Yamazoe and coworkers. ${ }^{7,11)}$ For the characterization of cell adhesion, Dulbecco's modified Eagle's medium (DMEM; Sigma-Aldrich D5648) was removed from the Petri dishes $24 \mathrm{~h}$ after cell seeding. The cells were washed 3 times with phosphate-buffered saline ( $\mathrm{pH}$ 7.4) to remove unattached cells and resuspended in DMEM. Then, attached cells were observed under a digital microscope (Keyence VHX-2000).

Since cell-adhesion characteristics have strong relationships with wettability and functional groups on the film surface, we conducted contact angle (CA) measurements (Kyowa DMe-201) and X-ray photoelectron spectroscopy (XPS; Physical Electronics 5700, X-ray source $\mathrm{Mg} \mathrm{K} \alpha$ ) of the films.

To investigate the effects of photons from APPJ, we irradiated APPJ on the samples covered with several UV transparent windows of $\mathrm{MgF}_{2}, \mathrm{CaF}_{2}, \mathrm{LiF}$, and $\mathrm{SiO}_{2}$. We also performed optical emission spectroscopy (OES) to determine active species in the DBD region of the tube and in the region $1 \mathrm{~cm}$ downstream of the nozzle. OES was performed using a monochromater (Princeton Instruments Acton SP-2358) equipped with a charge-coupled device and an image intensifier (Princeton Instruments Roper PI-MAX3). Optical emission from the jet was 

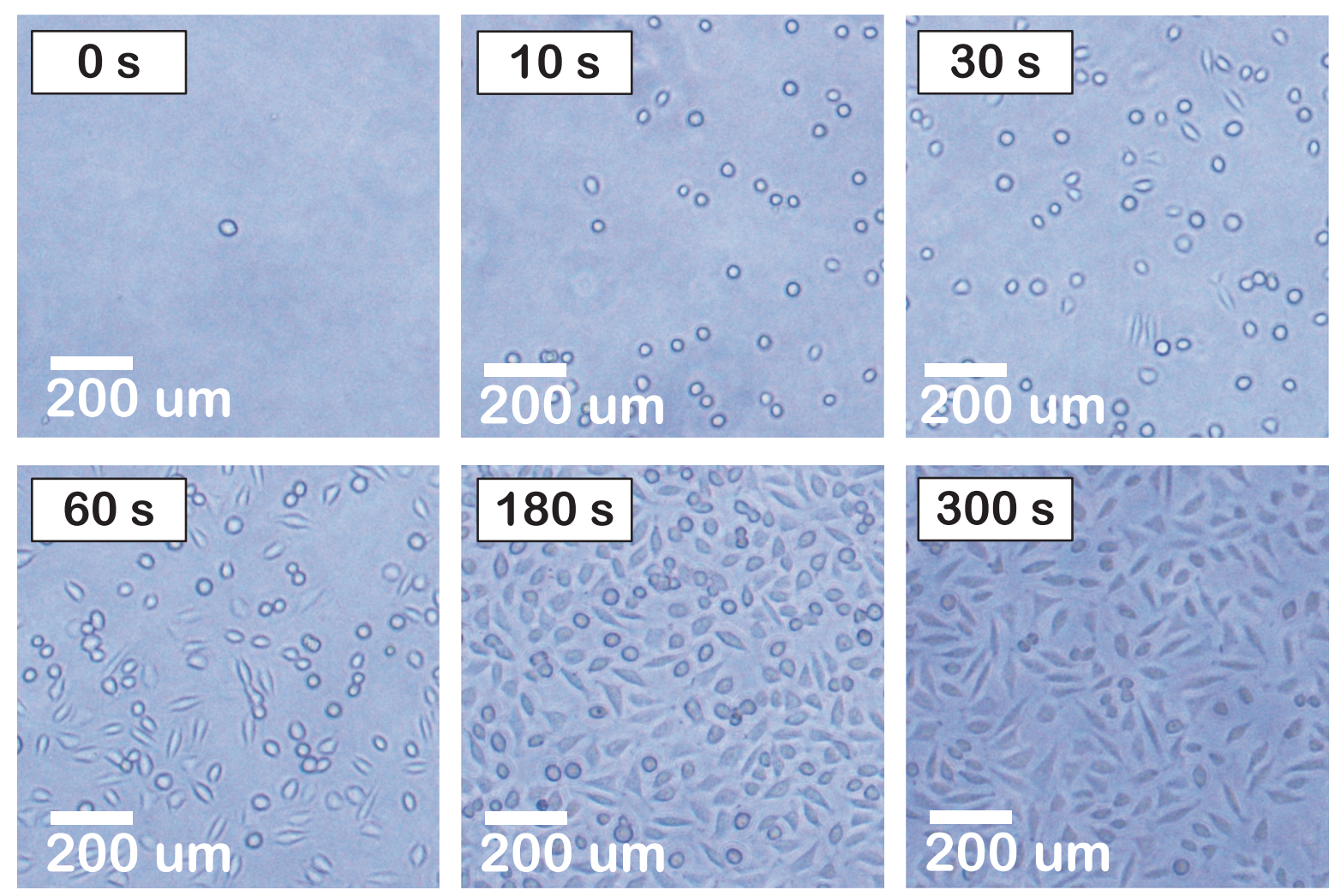

Fig. 2. (Color online) Cell-adhesion characteristics as a function of APPJ irradiation time.

collected through a UV-visible optical fiber.

\section{Results and discussion}

\subsection{Cell-adhesion characteristics}

Figure 2 shows cell-adhesion characteristics as a function of APPJ irradiation time. We confirmed that the number of attached cells increases with increasing irradiation time. Regarding the results after 180 and $300 \mathrm{~s}$, we observed that the cells elongated to show a spindlelike morphology in addition to saturation in cell density. One can observe the same phenomenon when cells firmly attach to surfaces as in the case of the surface of sticky bare culture dishes. ${ }^{9}{ }^{39,40)}$ In the case of UV photolithography, such firm cell-adhesion characteristics at $180 \mathrm{~s}$ in this work were observed after a $2 \mathrm{~h}$ exposure to UV light. ${ }^{7,11)}$ We hence estimated that APPJ irradiation provides a 40-fold faster increase in cell number than UV irradiation performed by Yamazoe and coworkers. ${ }^{7,11)}$

Since APPJ operated in atmosphere may contain reactive oxygen species, we have been concerned about the possibility of removing the crosslinked albumin film on a Petri dish by APPJ irradiation. ${ }^{41)}$ Thus, we tested the sample surface with Coomassie Brilliant Blue dye which stains proteins blue after APPJ irradiation. ${ }^{42-44)}$ Uder our present experimental 

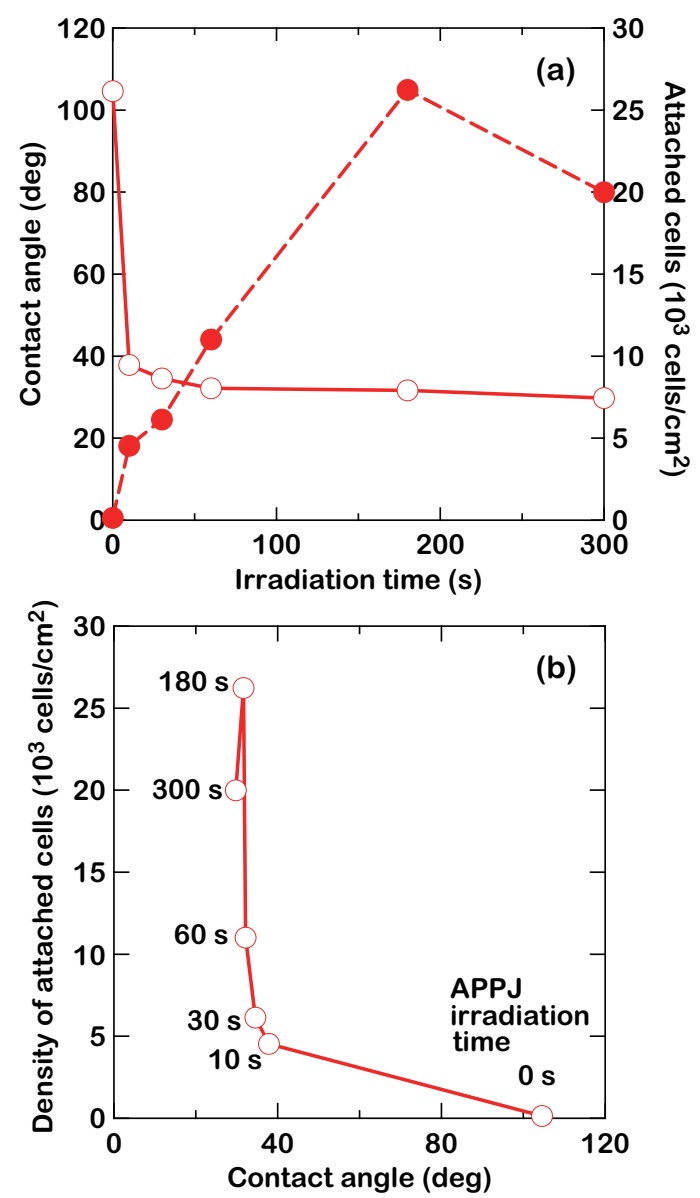

Fig. 3. (Color online) (a) Contact angle and density of cells attached to the samples irradiated with APPJ for $0,10,30,60,180$, and $300 \mathrm{~s}$. (b) Density of attached cells as a function of contact angle.

condition, all the films were stained blue, which means that the crosslinked albumin film completely covers the surface of a Petri dish even after the APPJ irradiation.

The cell-adhesion capability of surfaces is related to surface wettability governed by the surface coverage of hydrophilic functional groups, such as $\mathrm{COH}$ and $\mathrm{COOH}$. We hence performed CA and XPS measurements of the surface irradiated with APPJ.

\subsection{Surface characterization}

Figure 3(a) shows the CA to the surface and the density of attached cellsas a function of APPJ irradiation time. CA steeply decreases from 105 to $38^{\circ}$ for the first $10 \mathrm{~s}$, and decreases slightly from 38 to $32^{\circ}$ with increasing irradiation time from 10 to $180 \mathrm{~s}$. The number of cells attached to the surface, in contrast, almost linearly increases from $4.5 \times 10^{3}$ to $2.6 \times 10^{4}$ cells $/ \mathrm{cm}^{2}$ with increasing irradiation time up to $180 \mathrm{~s}$, as shown in the same figure. These results indicate that cell-adhesion capability cannot be explained simply in terms of the CA 


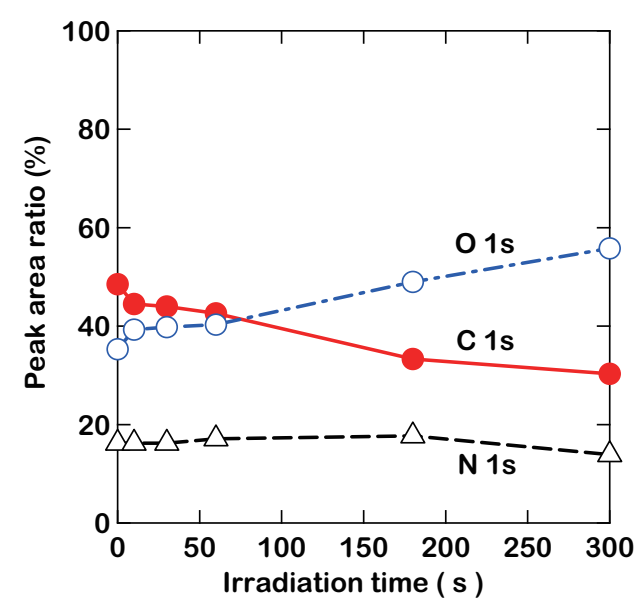

Fig. 4. (Color online) Normalized integrated peak intensities of C 1s, N 1s, and O 1s in the XPS spectra of the samples irradiated with APPJ for 0, 10, 30, 60, 180, and $300 \mathrm{~s}$.

to the surface. This can be understood by replotting the variation of the number of attached cells as a function of CA, as shown in Fig. 3(b), in which the number of attached cells does not show a linear relationship with CA including the reduction in the density of attached cells from 180 to $300 \mathrm{~s}$.

Arima and Iwata have revealed that the number of attached cells may differ between surfaces with the same CA if the surface functional groups are different. ${ }^{45)}$ They have reported that $\mathrm{COOH}$ groups provide a relatively larger number of adherent cells than simple $\mathrm{OH}$, as shown in their experimental results obtained by using substrates with self-assembled monolayers having these functional groups on their top surface.

Thus, we investigated the surface functional groups on the samples by XPS. Figure 4 shows the relative integrated peak intensities of $\mathrm{O} 1 \mathrm{~s}, \mathrm{C} 1 \mathrm{~s}$, and $\mathrm{N} 1 \mathrm{~s}$ as functions of APPJ irradiation time. The crosslinked albumin film without treatment shows $\mathrm{C} / \mathrm{N}$ and $\mathrm{C} / \mathrm{O}$ ratios of 3.0 and 1.4, respectively. These values are different from the theoretical $\mathrm{C} / \mathrm{N}$ and $\mathrm{C} / \mathrm{O}$ ratios of 3.2 and 3.7, respectively, for noncrosslinked albumin ${ }^{46)}$ because a crosslinking agent, which is ethylene glycol diglycidyl ether, is incorporated in the crosslinked albumin films. ${ }^{7,8)}$ The intensity of $\mathrm{O} 1 \mathrm{~s}$ gradually increases with increasing APPJ irradiation time. The intensity of $\mathrm{C} 1 \mathrm{~s}$ decreases accordingly. On the other hand, the intensity of $\mathrm{N} 1 \mathrm{~s}$ does not show a marked variation. This tendency indicates that the surface coverage of O-rich hydrophilic functional groups gradually increases with APPJ irradiation time.

For the purpose of detailed analysis of the surface functional groups, we deconvoluted the XPS spectra in the $\mathrm{C} 1 \mathrm{~s}$ region, as shown in Figs. 5(a)-5(f). We fitted a $\mathrm{C} 1 \mathrm{~s}$ profile with five peaks corresponding to C-C-H (285 eV), C-C-N (286 eV), C-C-O (287.5 eV), C-C=O 

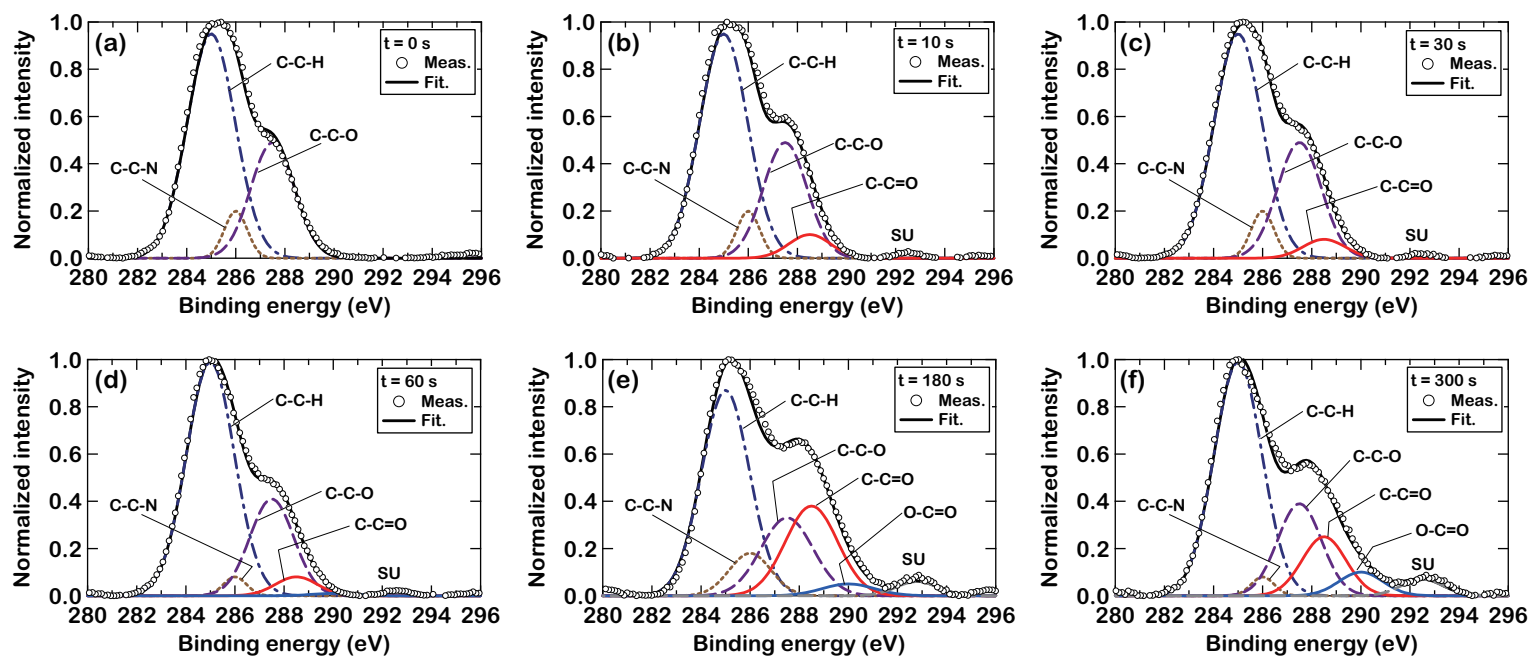

Fig. 5. (Color online) Spectra of C 1s region of the samples irradiated with APPJ for 0, 10, 30, 60, 180, and $300 \mathrm{~s}$.

$(288.5 \mathrm{eV})$, and $\mathrm{O}-\mathrm{C}=\mathrm{O}(290 \mathrm{eV}) .{ }^{47)}$ The $\mathrm{SU}$ means a shake-up peak. The relative intensities of the peaks for $\mathrm{C}-\mathrm{C}=\mathrm{O}$ and $\mathrm{O}-\mathrm{C}=\mathrm{O}$ groups tend to increase with increasing APPJ irradiation time, although they do not show monotonous variation. The $\mathrm{C}-\mathrm{C}=\mathrm{O}$ group appears after 10 $\mathrm{s}$ treatment, while the $\mathrm{O}-\mathrm{C}=\mathrm{O}$ group appears after $180 \mathrm{~s}$ treatment. The relative intensities of $\mathrm{C}-\mathrm{C}-\mathrm{H}, \mathrm{C}-\mathrm{C}-\mathrm{O}$, and $\mathrm{C}-\mathrm{C}-\mathrm{N}$, which are found in the untreated crosslinked albumin film, tend to decrease with increasing APPJ irradiation time. These results indicate that the original functional groups in crosslinked albumin films gradually converted to $\mathrm{C}-\mathrm{C}=\mathrm{O}$, which explains the gradual increase in the number of attached cells as a function of APPJ irradiation time.

Regarding the samples after $180 \mathrm{~s}$ treatment, their surfaces have the O-rich functional group of $\mathrm{O}-\mathrm{C}=\mathrm{O}$ in addition to $\mathrm{C}-\mathrm{C}=\mathrm{O}$. At the same time, attached cells show strong adhesion on the surface, as indicated by the elongated spindle-like morphology of the cells, although the number of attached cells decreases with increasing treatment time from 180 to $300 \mathrm{~s}$.

These results suggest that cell-adhesion strength and the number of cells attached to the surface have some relationships with the fractions of $\mathrm{C}-\mathrm{C}=\mathrm{O}$ and $\mathrm{O}-\mathrm{C}=\mathrm{O}$ on the surface. To clarify the relationships in detail, we need to investigate further the APPJ-irradiation from 100 to $300 \mathrm{~s}$, which is our future issue.

\subsection{Effects of VUV photons}

APPJ can be a light source for vacuum ultraviolet (VUV) photons with the wavelengths of 121.5 and $164 \mathrm{~nm}$ for $\mathrm{He}_{\mathrm{II}}$ and $120-175 \mathrm{~nm}$ for $\mathrm{N}_{\mathrm{I}}{ }^{48,49)}$ Although UV photons in the range of 200-300 nm may be emitted, their effects can be neglected because their treatment efficiency 

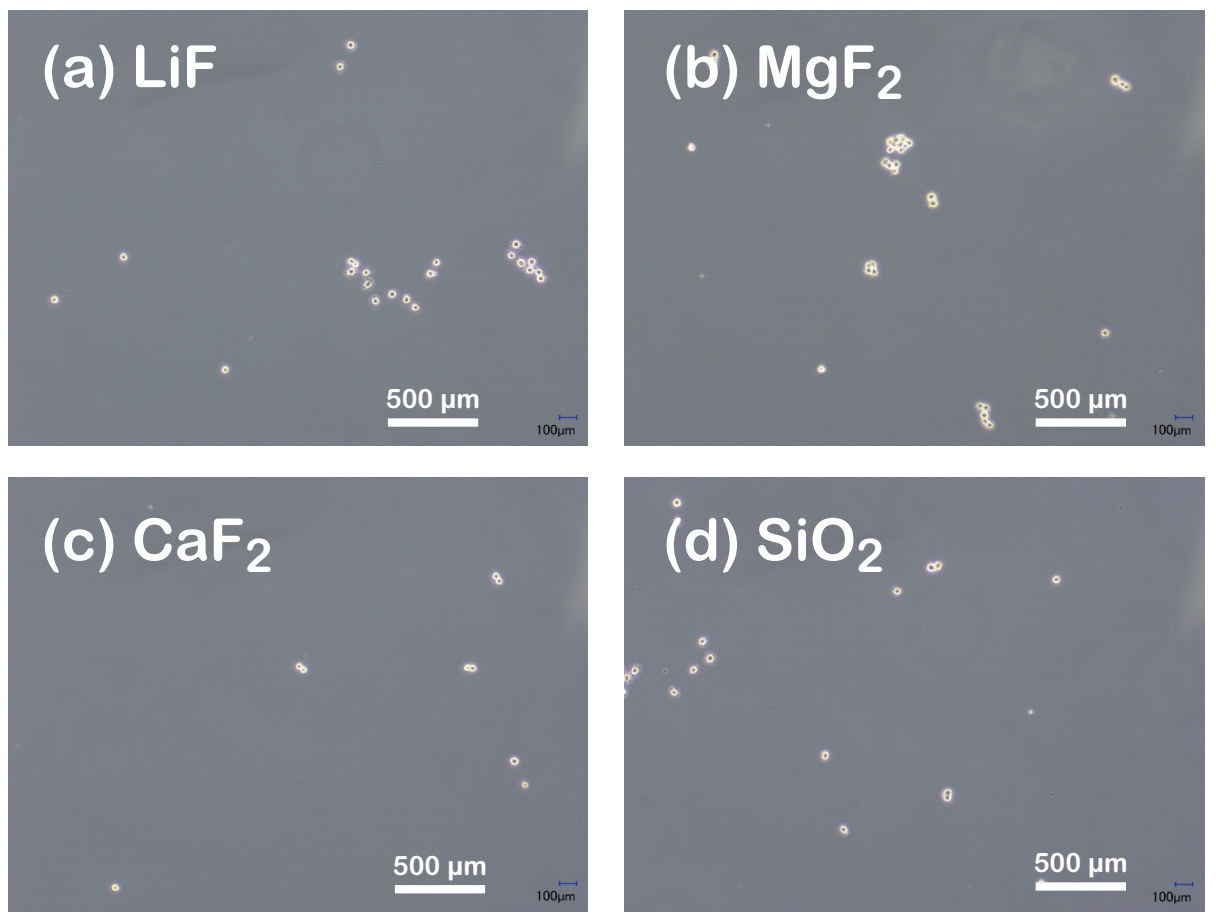

Fig. 6. (Color online) Characteristics of cell adhesion on the crosslinked albumin films irradiated with APPJ through the windows of (a) $\mathrm{LiF}$, (b) $\mathrm{MgF}_{2}$, (c) $\mathrm{CaF}_{2}$, and (d) $\mathrm{SiO}_{2}$.

at $254 \mathrm{~nm}$ is quite lower than that of APPJ irradiation. On the other hand, VUV photons have much higher energy than UV photons, and they can reach the substrate because they do not propagate in air, but in a helium-rich environment. In addition, VUV photons can modify chemical bonds in polymers. ${ }^{50,51)}$ Thus, we investigated the effects of VUV photons on the cell-adhesion characteristics by covering the crosslinked albumin films with the windows of $\mathrm{LiF}, \mathrm{MgF}_{2}, \mathrm{CaF}_{2}$, and $\mathrm{SiO}_{2}$ during APPJ irradiation. The thickness of the windows was 1 $\mathrm{mm}$. The cut-off wavelengths of $\mathrm{LiF}, \mathrm{MgF}_{2}, \mathrm{CaF}_{2}$, and $\mathrm{SiO}_{2}$ were 105, 110, 122, and $160 \mathrm{~nm}$, respectively. ${ }^{52)}$ The APPJ irradiation conditions were the same as those in the experiments without windows.

Figures 6(a)-6(d) show the cell-adhesion characteristics after the APPJ treatment through the windows for $180 \mathrm{~s}$, in which we can observe almost no cell adhesion. This means that the UV and VUV photons in APPJ irradiation have negligible effects on the acquisition of cell-adhesion capability of the surface of crosslinked albumin films.

\subsection{OES}

Since VUV photons are not responsible for the acquisition of the cell-adhesion capability of the crosslinked albumin films, we focused on the chemical species supplied from APPJ. 


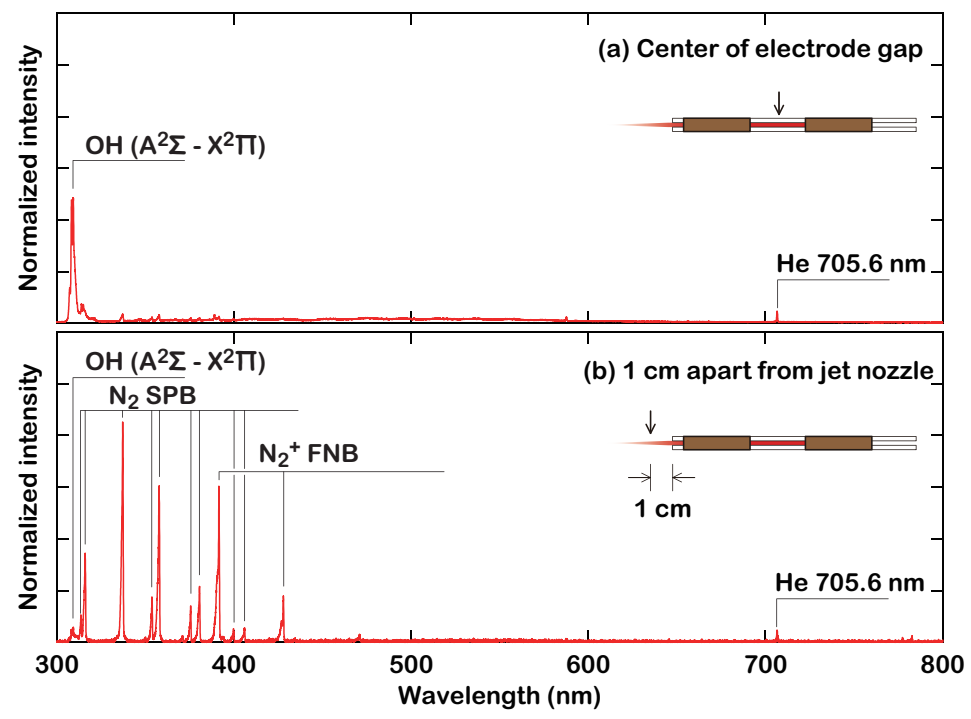

Fig. 7. (Color online) Optical emission spectra of APPJ observed (a) at the center of the electrode gap and (b) at the position $1 \mathrm{~cm}$ from the nozzle.

Figure 7(a) shows the OES profile at the center of the electrode gap, in which we can see a strong emission of $\mathrm{OH}\left(\mathrm{A}^{2} \Sigma-\mathrm{X}^{2} \Pi\right)[\mathrm{OH}(\mathrm{A})$, hereafter $]$ at $309 \mathrm{~nm} .{ }^{53)}$ The appearance of $\mathrm{OH}(\mathrm{A})$ in the quartz tube is due to degassing from a polyurethane tube used for feeding helium gas, since we do not intentionally feed water vapor.

Figure 7(b) shows the OES profile of the optical emission from the jet region $1 \mathrm{~cm}$ from the nozzle. We can see strong emission lines of the second positive system band (SPB) of $\mathrm{N}_{2}$ and the first negative system band (FNB) of $\mathrm{N}_{2}^{+} \cdot{ }^{54)}$ The appearance of these bands caused by short-lived excited energy levels means that excitation and ionization occur in the jet outside the tube. This result is due to the fact that the ionization front called the "plasma bullet" propagates in the jet region, and that APPJ is not a simple downstream of the discharge region in the tube. ${ }^{55,56)}$

On the other hand, we observe no optical emission of $\mathrm{O}$ at $777 \mathrm{~nm}$. We can observe $\mathrm{OH}(\mathrm{A})$ at $309 \mathrm{~nm}$ but its intensity is fairly low. Although we have expected strong emissions of these reactive oxygen species, the OES result suggests that they cannot be the cause of the increase in the $\mathrm{O} 1 \mathrm{~s}$ intensity in the XPS spectra. A possible cause is the formation of dangling bonds on the surface by excited species and the subsequent oxidation in ambient air or water vapor. ${ }^{57-61)}$ Since the ionization front propagates in APPJ and reach the sample surface, short-lived excited $\mathrm{N}_{2}$ and He may contribute for the formation of dangling bonds on the film surface in addition to long-lifetime metastable excited $\mathrm{N}_{2}$ and $\mathrm{He}$. 


\section{Conclusions}

We have applied an APPJ of He gas to surface treatment of crosslinked albumin films. The crosslinked albumin films, to which L929 cells do not attach by nature, acquire the L929 cell-adhesion capability following APPJ irradiation for quite a short time of $180 \mathrm{~s}$, which is 40-fold shorter than that in conventional UV photolithography technique reported by Yamazoe and coworkers. ${ }^{711)}$ The number of attached cells increases almost linearly with increasing APPJ irradiation time up to $180 \mathrm{~s}$. However, the variation in the number of attached cells cannot be explained simply in terms of CA of the samples because the CA does not show a linear relationship with APPJ irradiation time. XPS results indicate that the oxygen concentration on the surface increases almost linearly, which suggests that one of the key factors for the enhancement of cell-adhesion capability is the oxygen concentration on the surface rather than CA.

Some of the attached cells have an elongated spindle-like morphology on the samples irradiated for longer times (180 and $300 \mathrm{~s}$ ), which indicates that the cells show strong adhesion on the surface. Results of deconvolution of $\mathrm{C} 1 \mathrm{~s}$ spectra for these samples suggest that cell adhesion strength and the number of attached cells are affected by the fractions of $\mathrm{C}-\mathrm{C}=\mathrm{O}$ and $\mathrm{O}-\mathrm{C}=\mathrm{O}$, although details are not clarified yet.

UV and VUV photons from the irradiated APPJ have negligible effects on the acquisition of cell-adhesion capability of crosslinked albumin films. This means that the active species from APPJ are responsible for the acquisition of the cell-adhesion capability. The optical emission spectrum of APPJ, however, did not show strong emissions of $\mathrm{O}$ and $\mathrm{OH}$. These results suggest that the oxidized groups on the surface are not directly formed by $\mathrm{O}$ and $\mathrm{OH}$, but indirectly by other active species such as excited $\mathrm{N}_{2}$ and $\mathrm{He}$, presumably through the formation of dangling bonds by abundant excited $\mathrm{N}_{2}$ and $\mathrm{He}$, and the subsequent oxidation of dangling bonds in ambient air and/or water vapor.

\section{Acknowledgment}

This work was partly supported by JSPS/MEXT KAKENHI Grant Numbers 15H03585 and 15K13391. 


\section{References}

1) J. Melin and S. R. Quake, Annu. Rev. Biophys. Biomol. Struct. 36, 213 (2007).

2) C. S. Chen, M. Mrksich, S. Huang, G. M. Whitesides, and D. E. Ingber, Biotechnol. Prog. 14, 356 (1998).

3) M. Théry, J. Cell Sci. 123, 4201 (2010).

4) T. Vignaud, R. Galland, Q. Tseng, L. Blanchoin, J. Colombelli, and M. Théry, J. Cell Sci. 125, 2134 (2012).

5) A.-C. Reymann, J.-L. Martiel, T. Cambier, L. B. R. Boujemaa-Paterski, and M. Théry, Nature Mater. 9, 827 (2010).

6) K. Bhadriraju, W. F. Liu, D. S. Gray, and C. S. Chen, in BioMEMS and Biomedical Nanotechnology, eds. M. Ferrari, T. Desai, and S. Bhatia (Springer, New York, NY, 2006) Vol. 3, Chap. 18.

7) H. Yamazoe, T. Uemura, and T. Tanabe, Langmuir 24, 8402 (2008).

8) H. Yamazoe and T. Tanabe, J. Biomed. Mater. Res. A 86, 228 (2008).

9) H. Yamazoe, K. Yamauchi, and T. Tanabe, Mater. Sci. Eng. C 29, 1105 (2009).

10) H. Yamazoe and T. Tanabe, J. Biomater. Sci. 21, 647 (2010).

11) H. Yamazoe, H. Nakanishi, Y. Kashiwagi, M. Nakamoto, A. Tachibana, Y. Hagihara, and T. Tanabe, Langmuir 32, 203 (2016).

12) S. K. Bhatia, J. J. Hickman, and F. S. Ligler, J. Am. Chem. Soc. 114, 4432 (1992).

13) S. N. Bhatia, M. L. Yarmush, and M. Toner, J. Biomed. Mater. Res. 34, 189 (1997).

14) R. S. Kane, S. Takayama, E. Ostuni, D. E. Ingber, and G. M. Whitesides, Biomaterials 20, 2363 (1999).

15) R. J. Wade, E. J. Bassin, W. M. Gramlich, and J. A. Burdick, Adv. Mater. 27, 1356 (2015).

16) G. V. Shivshankar and A. Libchaber, Appl. Phys. Lett. 73, 417 (1998).

17) A. Schwarz, J. S. Rossier, E. Roulet, N. Mermod, M. A. Roberts, and H. H. Girault, Langmuir 14, 5526 (1998).

18) B. R. Ringeisen, J. Callahan, P. K. Wu, A. Piqué, B. Spargo, R. A. McGill, M. Bucaro, H. Kim, D. M. Bubb, and D. B. Chrisey, Langmuir 17, 3472 (2001).

19) P. K. Wu, B. R. Ringeisen, J. Callahan, M. Brooks, D. M. Bubb, H. D. Wu, A. Piqué, B. Spargo, R. A. McGill, and D. B. Chrisey, Thin Solid Films 398-399, 607 (2001).

20) D. B. Chrisey, A. Piqué, R. A. McGill, J. S. Horwitz, B. R. Ringeisen, D. M. Bubb, and P. K. Wu, Chem. Rev. 103, 553 (2003). 
21) M. Kim, J.-C. Choi, H.-R. Jung, J. S. Katz, M.-G. Kim, and J. Doh, Langmuir 26, 12112 (2010).

22) K. Itoga, J. Kobayashi, M. Yamato, and T. Okano, Method. Cell Biol. 119, 141 (2014).

23) A. Park, B. Wu, and L. G. Griffith, J. Biomater. Sci. Polym. Ed. 9, 89 (1998).

24) S. Xing, S. Zhao, and T. Pan, Method. Cell Biol. 119, 219 (2014).

25) M. Mrksich, L. E. Dike, J. Tien, D. E. Ingber, and G. M. Whitesides, Exp. Cell Res. 235, 305 (1997).

26) D. Qin, Y. Xia, J. A. Rogers, R. J. Jackson, X.-M. Zhao, and G. M. Whitesides, in Microsystem Technology in Chemistry and Life Science, eds. A. Manz and H. Becker (Springer, Berlin, 1998) p. 1.

27) G. P. Lopez, H. A. Biebuyck, R. Harter, A. Kumar, and G. M. Whitesides, J. Am. Chem. Soc. 115, 10774 (1993).

28) A. Nakao, M. Kaibara, M. Iwaki, Y. Suzuki, and M. Kusakabe, Surf. Interface Anal. 24, 252 (1996).

29) M. M. M. Bilek, Appl. Surf. Sci. 310, 3 (2014).

30) A. Kondyurin and M. Bilek, in Ion Beam Treatment of Polymers (Elsevier, Amsterdam, 2015) 2nd ed., Chap. 9.

31) Y. V. Pan, T. C. McDevitt, T. K. Kim, D. Leach-Scampavia, P. S. Stayton, D. D. Denton, and B. D. Ratner, Plasma. Polym. 7, 171 (2002).

32) T. G. van Kooten, H. T. Spijker, and H. J. Busscher, Biomaterials 25, 1735 (2004).

33) E. Sardella, R. Gristina, G. S. Senesi, R. d'Agostino, and P. Favia, Plasma Process. Polym. 1, 63 (2004).

34) E. Sardella, P. Favia, R. Gristina, M. Nardulli, and R. d'Agostino, Plasma Process. Polym. 3, 456 (2006).

35) J.-P. Frimat, H. Menne, A. Michels, S. Kittel, R. Ketter, S. Borgmann, J. Franzke, and J. West, Anal. Bioanal. Chem. 395, 601 (2009).

36) R. Picone, B. Baum, and R. McKendry, Method. Cell Biol. 119, 73 (2014).

37) H. Ayan, E. D. Yildirim, D. D. Pappas, and W. Sun, Appl. Phys. Lett. 99, 111502 (2011).

38) M. Teschke, J. Kedzierski, E. G. Finantu-Dinu, D. Korzec, and J. Engemann, IEEE Trans. Plasma Sci. 33, 310 (2005).

39) B. M. Gumbiner, Cell 84, 345 (1996).

40) D. A. Lauffenburger and A. F. Horwitz, Cell 84, 359 (1996).

41) K. Inomata, H. Koinuma, Y. Oikawa, and T. Shiraishi, Appl. Phys. Lett. 66, 2188 
(1995).

42) W. Diezel, G. Kopperschläger, and E. Hofmann, Anal. Biochem. 48, 617 (1972).

43) T. S. Meyer and B. L. Lamberts, Biochim. Biophys. Acta 107, 144 (1965).

44) T. H. Steinberg, in Guide to Protein Purification, eds. R. R. Burgess and M. P. Deutscher (Academic Press, San Diego, CA, 2009) 2nd ed., Chap. 31.

45) Y. Arima and H. Iwata, Biomaterials 28, 3074 (2007).

46) G. Iucci, G. Polzonetti, G. Infante, and L. Rossi, Surf. Interface Anal. 36, 724 (2004).

47) G. Beamson and D. Briggs, in High Resolution XPS of Organic Polymers The Scienta ESCA300 Database (John Wiley \& Sons, West Sussex, 1992) Chap. 15.

48) M. Kaku, T. Yamaura, T. Higashiguchi, S. Kubodera, and W. Sasaki, Jpn. J. Appl. Phys. 42, 3458 (2003).

49) A. Kramida, Y. Ralchenko, J. Reader, and NIST ASD Team, NIST Atomic Spectra Database (ver. 5.2), http://physics.nist.gov/asd. (National Institute of Standards and Technology, Gaithersburg, MD, 2014).

50) A. Holländer, J. E. Klemberg-Sapieha, and M. R. Wertheimer, J. Polym. Sci. A: Polym. Chem. 33, 2013 (1995).

51) A. Holländer, J. Behnisch, and M. R. Wertheimer, in Plasma Processing of Polymers, eds. R. d'Agostino, P. Favia, and F. Fracassi (Kluwer Academic, Dordrecht, 1997) p. 411.

52) T. Shirafuji, Ph.D. thesis, Kyoto University, Kyoto, Japan (1998).

53) R. W. B. Pearse and A. G. Gaydon, in The Identification of Molecular Spectra (Chapman and Hall, London, 1963) 3rd ed., p. 246.

54) R. W. B. Pearse and A. G. Gaydon, in The Identification of Molecular Spectra (Chapman and Hall, London, 1963) 3rd ed., p. 209.

55) K. Urabe, Y. Ito, K. Tachibana, and B. N. Ganguly, Appl. Phys. Express 1, 066004 (2008).

56) K. Urabe, T. Morita, K. Tachibana, and B. N. Ganguly, J. Phys. D 43, 095201 (2010).

57) H. Yasuda, J. Macromol. Sci.-Chem. A 10, 383 (1976).

58) E. M. Liston, L. Martinu, and M. R. Wertheimer, J. Adhesion Sci. Technol. 7, 1091 (1993).

59) C. Chan, T. Ko, and H. Hiraoka, Surf. Sci. Rep. 24, 1 (1996).

60) M. Nitschke and J. Meichsner, J. Appl. Polym. Sci. 65, 381 (1997).

61) D. Hegemann, H. Brunner, and C. Oehr, Nucl. Instrum. Methods Phys. Res. B 208, 281 (2003). 